Research Report

\title{
Nerve growth factor: a mitogenic signal for retinal Müller glial cells
}

\author{
Tsunehiko Ikeda, Donald G. Puro * \\ Departments of Ophthalmology and Physiology, Unicersity of Michigan, W.K. Kellogg Eye Center, 1000 Wall Street, Ann Arbor, MI 48105, USA
}

(Accepted 15 March 1994)

\begin{abstract}
Knowledge of the effects of nerve growth factor (NGF) on glia is limited. A CNS site where NGF-glial interactions may occur is the retina. NGF is endogenous to the retina, and the retinal Müller glial cells have NGF receptors. Here, we cxamined the possibility that NGF may be a mitogen for Müller glial cells, which often proliferate in response to pathophysiological conditions. Experiments were performed on cultured glial cells from the adult human retina. Exposure of cultured Müller glial cells to $2.5 \mathrm{~S}$ NGF under serum-free conditions resulted in a concentration-dependent increase in cell number and bromodeoxyuridine incorporation into nuclei. The half-maximally effective concentration was $0.04 \mathrm{ng} / \mathrm{ml}(1.5 \mathrm{pM})$, consistent with activation of high affinity NGF receptors. K252a, a blocker of the neurotrophin family of tyrosine kinase-linked receptors, potently inhibited the proliferative effect of NGF. Transforming growth factor $\beta-2$, another growth factor endogenous to the retina, inhibited the mitogenic response to NGF. These findings indicate that human Müller glial cells in culture express functional NGF receptors and that the response of Müller cells to NGF can be modulated by other growth factors.
\end{abstract}

Key words: Neurotrophin; Transforming growth factor $\beta-2$; Glia; Proliferation; trk receptor

\section{Introduction}

It is established that certain neurons in the PNS and CNS are targets for nerve growth factor (NGF). Less well-understood are the interactions between this growth factor and glial cells. In the mammalian retina, Müller glial cells express high and low affinity NGF receptors $[4,8,18,22,25,31]$. Since NGF is endogenous to the retina [4], these glial NGF receptors are likely to be of functional significance. However, at present, little is known about the function of this neurotrophin in the retina. Here, we examined the possibility that one role of retinal NGF is to serve as a mitogenic signal for the Müller glial cells.

Glial cells of the retina, as in other parts of the nervous system, often proliferate in response to pathophysiological conditions. The proliferation of glia may be an important factor in compromising neural function after disease or injury. For example, Müller cell proliferation in the eye appears to be a significant

* Corresponding author. Fax: (1) (313) 936-2340. cellular event associated with irreversible loss of function caused by detachment of the neural retina from the underlying retinal pigment epithelium $[5,7,29]$.

Although glial proliferation is likely to play a significant role in retinal pathobiology, knowledge concerning the regulation of the proliferative response of the Müller glial cells is limited. To detect a proliferative effect of NGF, we used cultures of Müller glial cells derived from the adult human retina. An advantage of a cell culture system was the ability to quantify a mitogenic effect of NGF on human retinal glial cells under serum-free conditions in the absence of significant numbers of non-glial cells.

We report that picomolar concentrations of NGF can stimulate the proliferation of retinal Müller glia in culture. These findings support the hypothesis that NGF may serve as a mitogenic signal for Müller glial cells of the retina.

\section{Materials and methods}

Cultures of retinal glial cells were prepared as detailed elsewhere [19]. Postmortem eyes from donors aged 31-74 years were supplied 
within $24 \mathrm{~h}$ of death by the Michigan Eye Bank. Retinas were removed, exposed to a calcium- and magnesium-free phosphate buffer supplemented with $0.1 \%$ trypsin $(3 \times$ crystallized; Worthington), $0.2 \%$ hyaluronidase (Sigma) and $4 \%$ chicken serum (Gibco) for $45 \mathrm{~min}$ at $37^{\circ} \mathrm{C}$ and then dissociated mechanically in $80 \%$ medium $\mathrm{A}$ (1:1 ratio of Dulbecco's modified Eagle's medium (Gibco) and Ham's F12 medium (Gibco)) plus $20 \%$ fetal bovine serum (FBS). Dissociated cells from one retina were added to three $35-\mathrm{mm}$ Petri dishes, kept in a humidified environment of $96.5 \%$ air $/ 3.5 \% \mathrm{CO}_{2}$ at $37^{\circ} \mathrm{C}$ and fed with $80 \%$ medium A plus $20 \%$ FBS twice per week. Cells that had been in culture for 2-6 passages were used. As reported elsewhere, virtually all of the cells prepared by this method are immunoreactive to a monoclonal antibody specific for retinal Müller glial cells [21] and to polyclonal antibodies against glutamine synthetase [28], which is localized in the retina to the Müller glial cells [13]. Thus, immunocytochemical markers indicate that the cells in these cultures are Müller cells.

Changes in cell number were measured as described previously [21]. In brief, Müller glial cells from near confluent cultures were exposed to trypsin, suspended in $80 \%$ medium A plus $20 \%$ FBS and plated at a low density on grids of 676 labeled squares imprinted on 35-mm dishes. After 2 days, a baseline cell count was done by starting at one corner of the grid and proceeding until at least 100 cells had been counted. The culture dishes then exposed to serumfree medium supplemented with murine 2.5S NGF (Sigma), K252a (Kamiya Biomedical), recombinant human transforming growth factor $\beta-2$ (TGF $\beta-2$; Austral Biologicals), phorbol-12-myristate-13acetate (LC Laboratories) or recombinant human basic fibroblast growth factor (bFGF, R\&D Systems) for 2 days (Figs. 1, 2, 4, 5) or variable times (Fig. 3). Two days after the initial cell counting, the same areas of the grids were recounted.

In experiments examining the incorporation of bromodeoxyuridine (BrdU) into DNA of glial nuclei, cells on grid-stamped dishes were exposed for 2 days to $10 \mu \mathrm{M} \mathrm{BrdU}$ in medium $\mathrm{A}$ with or without NGF. BrdU was localized by immunocytochemical methods [28]. In brief, cultures were fixed with $70 \%$ ethanol, bathed in $2 \mathrm{M}$ $\mathrm{HCl}$ followed by $0.1 \mathrm{M}$ sodium borate $(\mathrm{pH} 9)$ for $10 \mathrm{~min}$ each and then exposed to a monoclonal antibody to $\operatorname{BrdU}(1: 50$, Becton Dickinson) for $1 \mathrm{~h}$ at room temperature. Subsequently, the cultures were incubated in biotinylated anti-mouse IgG antibody $(1: 1000$, Vector) for $1 \mathrm{~h}$ at room temperature followed by application of an

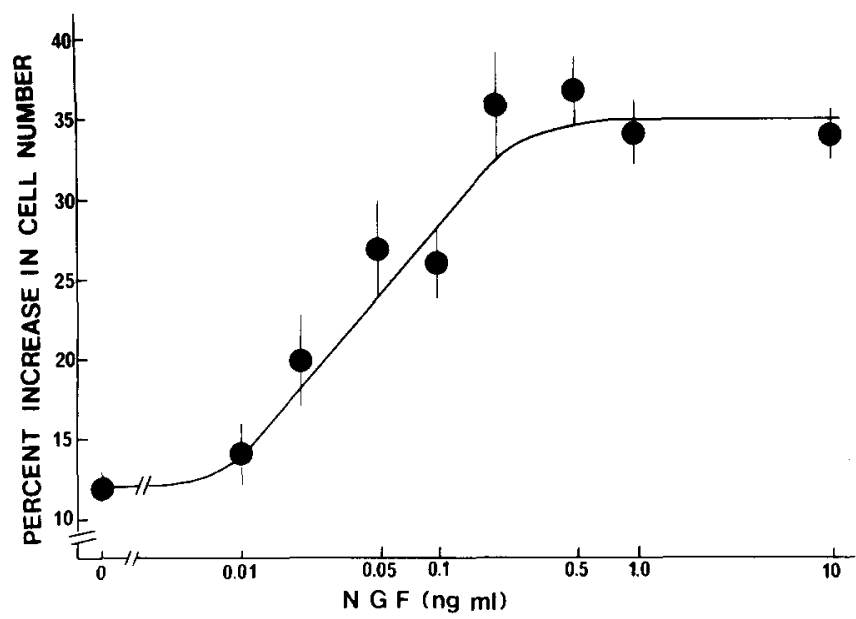

Fig. 1. The effect of various concentrations of NGF on the proliferation Müller glial cells. The percent increase in cell number was determined after a 2-day exposure to NGF under serum-free conditions. Each value represents the mean $( \pm$ S.E.M. $)$ of at least four experiments.

\section{PERCENT INCREASE IN LABELED NUCLEI}

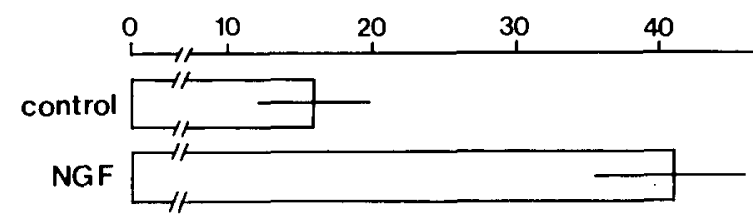

Fig. 2. The effect of NGF on BrdU incorporation into Müller cell nuclei. Each value represents the mean $( \pm . S . E . M$.$) of at least three$ experiments.

avidin-biotin-peroxidase complex $(1: 100$, Vector) with development in diaminobenzidine.

\section{Results}

Fig. 1 shows the effect of various concentrations of 2.5 S NGF on the proliferation of retinal Müller glial cells in culture. A concentration-dependent increase in the number of glial cells occurred under serum-free conditions. The increases in cell number at concentrations $\geq 0.02 \mathrm{ng} / \mathrm{ml}$ were significant $(P \leq 0.002$, Student's $t$-test). The half-maximally effective concentration of NGF was $0.04 \mathrm{ng} / \mathrm{ml}(1.5 \mathrm{pM})$. A maximal stimulatory effect occurred at concentrations greater $\geq 0.2 \mathrm{ng} / \mathrm{ml}$. These cell counting experiments strongly indicate that NGF can stimulate the proliferation of retinal Müller glial cells.

To help confirm by an independent assay that NGF is mitogenic, we assessed the effect of NGF on the incorporation of BrdU into the nuclei of the glial cells. $\mathrm{BrdU}$, an analog of the nucleotide thymidine, is incorporated into replicating DNA and can be detected by immunocytochemistry using an anti-BrdU monoclonal antibody. Cultures of Müller cells were exposed for 2 days to serum-free medium plus $10 \mu \mathrm{M}$ BrdU with or without NGF (1 $\mathrm{ng} / \mathrm{ml})$. Immunocytochemistry revealed that significantly $(P<0.001$, Student's $t$-test $)$ more nuclei in the NGF-treated group stained positively than in the control plates (Fig. 2). These experiments demonstrate that NGF is a mitogen for the human retinal Müller glia in our culture system.

The effect of the duration of exposure to NGF on retinal glial cell proliferation was also assessed. This was of interest since cells often require many hours of exposure to growth factors in order for proliferation to occur [24]. In Fig. 3, glial cultures were exposed to serum-free medium supplemented with $0.5 \mathrm{ng} / \mathrm{ml}$ NGF. At various times, some cultures were switched to NGF-free medium. All cultures were assayed for a change in cell number at $48 \mathrm{~h}$. Exposure to NGF for 10 $\mathrm{h}$ or less did not significantly $(P>0.7$, Student's $t$-test) stimulate cell proliferation. However, retinal glial cell proliferation did increase significantly $(P \leq 0.002$, Stu- 


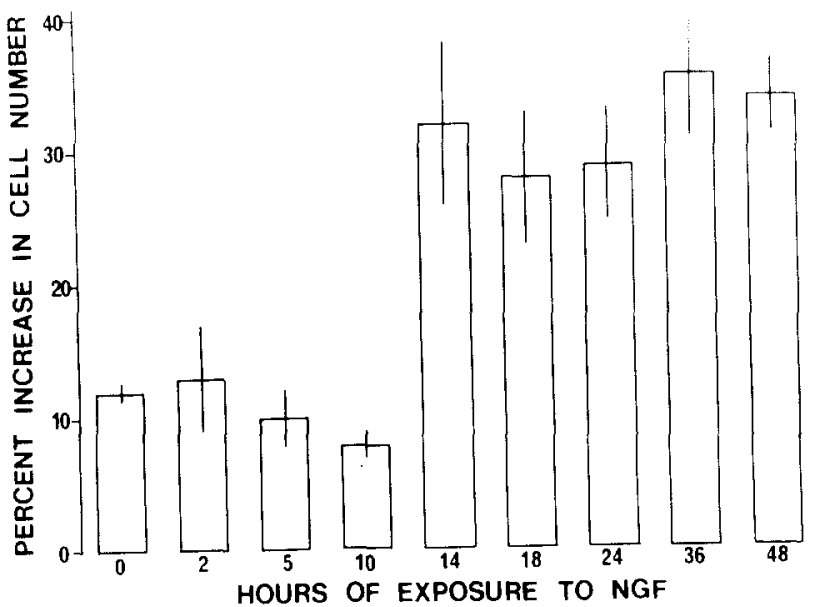

Fig. 3. The effect of the duration of exposure to NGF on the proliferation of retinal Müller glial cells. Cultures were exposed to serum-free medium supplemented with $0.5 \mathrm{ng} / \mathrm{ml} \mathrm{NGF}$ for various periods of time then washed and maintained in a medium without NGF or serum. The proliferation assay was completed 2 days after the onset of the experiment. Each value represents the mean $( \pm$ S.E.M. $)$ of at least four experiments.

dent's $t$-test) with exposure times of $14 \mathrm{~h}$ or more. Thus, a period of hours of exposure to NGF is required to induce mitogenesis in these cells under the conditions used here.

We examined the effect of K252a, an alkaloid-like compound that potently inhibits NGF-induced biological responses by blocking the tyrosine kinase activity of the trk family of neurotrophin receptors $[2,11,27]$. As shown in Fig. 4, $100 \mathrm{nM}$ K252a significantly $(P=0.001$, Student's $t$-test) reduced the proliferative response of Müller glial cells to NGF. This was not a nonspecific inhibitory effect since K252a did not significantly ( $P=$ 0.611 , Student's $t$-test) affect proliferation induced by basic fibroblast growth factor, a retinal glial mitogen [20] that activates another family of tyrosine kinase-linked receptors [26]. These pharmacological experiments support the idea that NGF activates a trk receptor to induce a proliferative response in Müller glial cells.

Since glia in the adult retina do not normally proliferate, the possibility was raised that other growth fac-

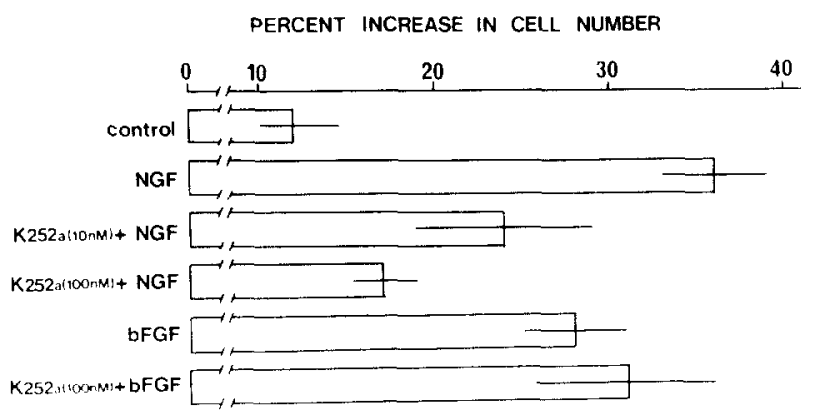

Fig. 4. The effect of K252a on the proliferation of Müller glial cells induced by $1 \mathrm{ng} / \mathrm{ml} \mathrm{NGF}$ or $50 \mathrm{pg} / \mathrm{ml} \mathrm{bFGF}$. Each value represents the mean $( \pm$ S.E.M. $)$ of at least three experiments.

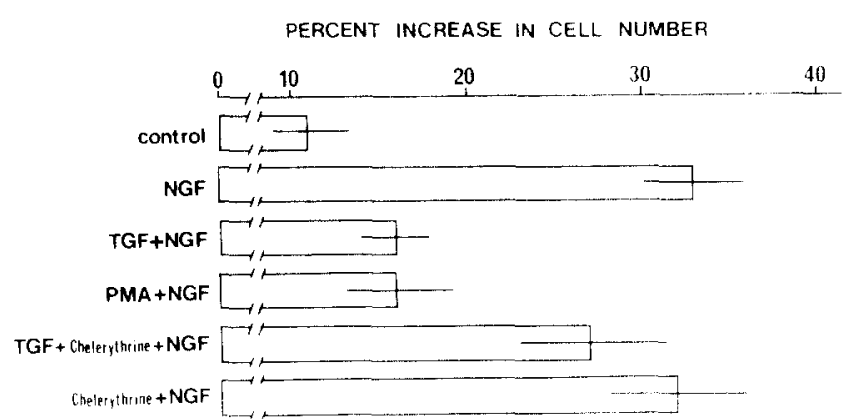

Fig. 5. The effect of TGF $\beta-2$ on the NGF-induced proliferation of retinal Müller glial cells in culture. Cells were exposed to $0.2 \mathrm{ng} / \mathrm{ml}$ NGF, $1 \mathrm{ng} / \mathrm{ml}$ TGF $\beta-2,100 \mathrm{nM}$ phorbol-12-myristate-13-acetate and $/$ or $0.5 \mu \mathrm{M}$ chelerythrine. See text for details. Each value represents the mean $( \pm$ S.E.M. $)$ of at least three experiments.

tors may block the mitogenic effect of NGF. We tested TGF $\beta-2$, which is endogenous to the retina [14] and a known modulator of responses to growth factors. Fig. 5 shows that TGF $\beta-2$ markedly reduced the proliferative effect of NGF $(P<0.001$, Student's $t$-test $)$. In some other cell types, TGF $\beta-2$ activates protein kinase C. In our culture system, exposure of the glial cells to phorbol-12-myristate-13-acetate, an activator of protein kinase $\mathrm{C}$, significantly reduced $(P=0.003$, Student's $t$ test) the proliferative effect of NGF (Fig. 5). Further evidence for a role of protein kinase $C$ was that the specific protein kinase $C$ inhibitor, chelerythrine [6], blocked the inhibitory effect of TGF $\beta-2$ on the NGFinduced proliferation (Fig. 5). This series of experiments shows that TGF $\beta-2$ profoundly reduces the mitogenic effect of NGF and suggests that activation of protein kinase $\mathrm{C}$ mediates this inhibitory effect.

\section{Discussion}

The results show that picomolar concentrations of NGF induce a mitogenic response in human Müller glial cells in culture. Pharmacological experiments indicate that this response to NGF involves a tyrosine kinase and can be down-regulated by TGF $\beta-2$ via activation of protein kinase $C$. This is the first report showing evidence for the presence of functional high affinity NGF receptors on glial cells.

Retinal glial cells may be the only glia normally expressing NGF receptors. In vivo, Müller glial cells have both high and low affinity NGF receptors $[4,8,18,22,25,31]$. Although apparently lacking NGF receptors under physiological conditions, astrocytes [9], oligodendrocytes [1] and Schwann cells [10] may express NGF receptors in culture or in response to injury. At present, the biological role of high affinity NGF receptors expressed by non-retinal glia is unknown. Effects of relatively large (nanomolar) concentrations of NGF on glia are varied. In vitro, NGF enhances mitogenesis in oligodendrocytes [1], but sup- 
presses the proliferation of various glial tumor cells $[12,16,30]$. Also, nanomolar concentrations of NGF can up-regulate neurotrophin receptors on astrocytes and C6 glioma cells $[9,12]$. The signal transduction pathways for these various effects of high concentrations of NGF remain to be elucidated.

The concentration of NGF for half-maximal stimulation of proliferation of cultured Müller cells is 1.5 $\mathrm{pM}$. The effectiveness of picomolar concentrations of NGF complements our immunocytochemical evidence for the presence of high affinity neurotrophin receptors on cultured Müller cells and helps establish the presence of functional high affinity NGF receptors on these glial cells. If the $K_{\mathrm{d}}$ of binding for the high affinity NGF receptors on Müller cells is the same as for neurons $\left(2.3 \times 10^{-11} \mathrm{M}\right)$ [17], then only a relatively small percentage of the high affinity receptors need to be occupied to induce a mitogenic response.

The sensitivity of Müller cells to NGF raises a question. If Müller cells express high affinity NGF receptors in vivo, then why do they not proliferate under normal conditions in response to the endogenous NGF in the retina? One possible answer is that the Müller cells in vivo are not exposed to NGF for a sustained period of $14 \mathrm{~h}$ or more, which our results show is required to induce mitogenesis. Alternatively, our experiments with TGF $\beta-2$ may indicate a more likely reason why Müller cells do not normally proliferate. We found that TGF $\beta$-2, which is present in the human retina [14], markedly inhibits the NGF-induced proliferation of Müller cells. This inhibition of proliferation is blocked by a protein kinase $\mathrm{C}$ inhibitor and is mimicked by a phorbol ester which activates protein kinase C. Perhaps growth factors such as TGF $\beta-2$ block the mitogenic effect of NGF in the retina under normal conditions. In contrast, under pathological conditions, decreased exposure of Müller glia to TGF $\beta-2$ and other mitogenic suppressants may release the NGF-induced mitogenic pathway from inhibition.

Although NGF may serve as a mitogenic signal for Müller glia under pathophysiological conditions, the function of NGF receptors in the retina under normal conditions remains to be determined. Interestingly, Müller cells of the mammalian retina appear to synthesize NGF [4]. Thus, NGF may have an autocrine function to help regulate responses of Müller cells to physiological and pathophysiological conditions.

\section{Acknowledgements}

This work was supported in part by Grants EY 06931 and EY 07003 from the National Eye Institute, NIH, Bethesda, MD.D.G.P. is a Research to Prevent Blindness Senior Scientific Investigator.

\section{References}

[1] Althaus, H.H., Kloppner, S., Schmidt-Schultz, T. and Schwartz, P., Nerve growth factor induces proliferation and enhances fiber regeneration in oligodendrocytes isolated from adult pig brain, Neurosci. Lett., 135 (1992) 219-223.

[2] Berg, M.M., Sternberg, D.W., Parada, L.F. and Chao M.V., $\mathrm{K}-252 \mathrm{a}$ inhibits nerve growth factor-induced trk proto-oncogene tyrosine phosphorylation and kinase activity, J. Biol. Chem., 267 (1992) 13-16.

[3] Blumberg, P.M., In vitro studies on the mode of action of the phorbol esters, potent tumor promoters, Part 2, Crit. Rev. Toxicol, 8 (1981) 199-234.

[4] Chakrabarti, S., Shima A.A., Lee, J., Brachet, P. and Dicou, E., Nerve growth factor (NGF), proNGF receptor-like immunoreactivity in BB rat retina, Brain Res., 523 (1990) 11-15.

[5] Fisher, S.K. and Anderson, D.H., Cellular effects of detachment on the neural retina and the retinal pigment epithelium. In S.J. Ryan (Ed.) Retina, Chapter 123, C.V. Mosby Co., St. Louis, 1989.

[6] Herbert, J.M., Augereau, J.M., Gleye, J. and Maffrand, J.P., Chelerythrine is a potent and specific inhibitor of protein kinase C, Biochem. Biophys. Res. Commun., 172 (1990) 993-999.

[7] Hiscot, P.S., Grierson, I., Trombetta, C.J., Rahi, A.N.S., Marshall, J. and McLeod D., Retinal and epiretinal glia: An immunohistochemical study, Br. J. Ophthalmol., 68 (1984) 698-707.

[8] Hopkins, J.M., Kleitman, N. and Spiegel, K., The p75 neurotropin receptor in human retina, Soc. Neurosci. Abstr., 18 (1992) 1290.

[9] Hunton, L.A., de Vellis, J. and Perez-Polo, J.R., Expression of p $75^{\text {NGFR }}$, trkA, and trkB mRNA in rat C6 glioma and type I astrocyte cultures, J. Neurosci. Res., 32 (1992) 375-383.

[10] Johnson, Jr., E.M., Taniuchi, M. and DiStefano, P.S., Expression and possible function of nerve growth factor receptors on Schwann cells, Trends Neurosci., 11 (1992) 299-304.

[11] Knüsel, B. and Hefti, F., K-252a compounds: Modulators of neurotrophin signal transduction, J. Neurochem., 59 (1992) $1987-1996$

[12] Kumar, S., Huber, J., Peña, L.A., Perez-Polo, J.R., WerrbachPerez, K. and de Vellis, J.. Characterization of functional nerve growth factor-receptors in a CNS glial cell lines; monoclonal antibody $217 \mathrm{c}$ recognizes the nerve growth factor-receptor on C6 glioma cells, J. Neurosci. Res., 27 (1990) 408-417.

[13] Lewis, G.P., Erickson, P.A., Kaska, D.D. and Fisher, S.K., An immunocytochemical comparison of Müller cells and astrocytes in the cat retina, Exp. Eye Res., 47 (1988) 839-853.

[14] Lutty, G.A., Merges, C. Threlkeld, A.B., Crone, S. and McLeod D.S., Heterogeneity in localization of isoforms of TGF- $\beta$ in human retina, vitreous and choroid, Invest. Ophthalmol. Vis. Res., 34 (1993) 477-487.

[15] Markovac, J. and Goldstein, G.W., Transforming growth factor beta activates protein kinase $\mathrm{C}$ in microvessels isolated from immature rat brain, Biochem. Biophys. Res. Commun., 150 (1988) $575-582$.

[16] Marushige, Y., Raju, N.R., Marushige, K. and Koestner, A., Modulation of growth and of morphological characteristics in glioma cells by nerve growth factor and glia maturation factor, Cancer Res., 47 (1987) 4109-4115.

[17] Meakin, S.O. and Shooter, E.M., The nerve growth factor family of receptors, Trends Neurosci., 15 (1992) 323-331.

[18] Merighi, A., Camignoto, G., Ghidella, S., Lipartiti, M., Zanellato, A. and Comelli. C., The trk proto-oncogene product p140 is expressed by ganglion cells of the human retina, Soc. Neurosci. Abstr., 18 (1992) 948.

[19] Puro, D.G., Calcium channels of human retinal glial cells. In T. 
Narahashi (Ed.) Methods of Neuroscience. Vol. 19. Academic Press. Orlando, FL. 1994.

[20] Puro. D.G. and Mano, T., Modulation of calcium channels in human retinal glial cells by basic fibroblast growth factor: a possible role in retinal pathobiology, J. Neurosci. 11 (1991) $1873-1880$.

[21] Puro, D.G., Mano. T., Chan, C., Fukuda, M. and Shimada, H., Thrombin stimulates the proliferation of retinal glial cells. Graefe's Arch. Clin. Exp. Ophthalmol., 228 (1990) 169-173.

[22] Radeke, M.J., Lewis, G.P., Blumberg, D., Fisher, S.K. and Feinstein. S.C., Localization of neurotrophin receptors in normal and degenerating cat retina, Soc. Neurosci. Abstr., 19 (1993) 1304.

[23] Robertson, P.L., Markovac, J., Datta, S.C. and Goldstein, G.W., Transforming growth factor beta stimulates phosphoinositol metabolism and translocation of protein kinase $C$ in cultured astrocytes, Neurosci. Lett., 93 (1988) 107-113.

[24] Rozengurt, E., Early signals in the mitogenic response, Science. 234 (1986) 161-166.

[25] Schatteman, G.C.. Gibbs, L.. Lanahan. A.A.. Claude, P. and Bothwell. M.. Expression of NGF receptor in the developing and adult primate central nervous system. I. Viaremes. \& (198s) $860-873$.

[26] Schlessinger, J. and Ullrich. A. Growth factor signaling by receptor tyrosine kinases, Neurom. 9 (1992) 383-391.

27] Tapley, P., Lamballe, F. and Barbacid, M.. K252a is a selective inhibitor of the tyrosine protein kinase activity of the trk family of oncogenes and neurotrophin receptors. Oncegene, 7 (1992) $371-381$.

[28] Uchihori, Y. and Puro, D.G., Glutamate as it neuron-to-glial signal for mitogenesis: role of glial $\mathrm{N}$-methyl-D-aspartate receptors, Brain Res, 613 (1993) 212-220).

[29] Van Horn, D.L., Aaberg, 'T.M., Machemer. R. and Fenzl, R. Glial cell proliferation in human retinal detachment with massive periretinal proliferation, Am J. Ophthalmol. 84 (1977) $383-393$

[30] Vinores. S.A. and Koestner, A., The effect of nerve growth factor on undifferentiated glioma cells, Cancer l.eft. 10) (1980) $309-318$.

[31] Yan, G. and Johnson, Jr., E.M.. An immunocytochemical study of the nerve growth factor receptor in developing rats. I. Neltrosci. 8 (1988) $3481-3498$. 